\title{
Creating Magical Research: Writing for a Felt Reality in a More-Than-Human World
}

\author{
Nicole Bowers
}

Riding the conceptual currents of the anarchive (E. Manning, October 30,2018 , personal communication) and non-representational methodologies (Vannini, 2015), I seek lively text in writing about nature, sustainability, and the environment and novel, playful ways of writing "research" of the same. Driven by a search for potentiated experiences for readers and writers in academic work, I reach toward magical realism to experiment with infusing my own writing practices with radioactive elements that exceed the static, informational text so often seen in normative science education articles. I propose to play with the writing of research through infusion of magical realism, engaging myself and readers in a tapestry of text that hopes to create "the real-the limit events that resist representation-as an immediate, felt reality" (Arva, 2008, p. 60).

It is no revelation that we live in precarious times. We, more-than-humans, have a new way of being in the world to grapple with; we face issues of climate change and environmental degradation as well as issues of poverty and displacement in a heightened and collective state. We have more forest fires, stronger hurricanes, more extreme floods, and longer droughts to look forward to (Allen et al., 2018). We can expect to deal with water shortages, food supply disruptions, land destruction, and mass migration of climate refugees (Miller, 2017; Rogelj et al., 2018). The International Panel on Climate Change (IPCC) report is quite clear on predicting what will happen,

N. Bowers $(\varangle)$

Arizona State University, Temp, AZ, USA

e-mail: nbowers1@asu.edu 
and many scientists believe their predictions to be conservative (Butzer \& Endfield, 2012).

Meanwhile, neoliberal politicians act to exacerbate the processes of unsustainability that brought us to this point in the first place. Late capitalism thrives on technologically enhanced modes of extraction and production to ensure continued economic growth with little regard for the natural and physical limits or consequences of that growth (MacGregor, 2014; Plumwood, 2002). Additionally, government programs have been gutted through deregulation and privatization, rendering them incapable of dealing with growing dire environmental and societal issues. The lack of market regulation has served to increase capital accumulation by the wealthy while decreasing opportunities and security for everyone else (Harvey, 2005). Over the past 40 years of neoliberalism, the growth rate of the economy remains the same as the rate prior to neoliberalism, but what has increased significantly is the percent of growth shared by wealthy elites (Harvey, 2005; Piketty, 2014). In addition to these economic and legislative mechanisms, neoliberalism acts as a "powerful public pedagogy" (Giroux, 2005, p. 14), so much so, that it may be easier to imagine the end of the world than the end of neoliberalism (Giroux, 2005).

These precarious times have been encapsulated by the contested term, the Anthropocene. Although the Anthropocene is seen by natural scientists as a problem of human activity and environmental degradation, many social scientists and researchers in the humanities also see it as a problem with entrenched ways of thought (Baskin, 2015; Johnson \& Morehouse, 2014; Lövbrand et al., 2015). Analysis of the debates and discourse around the mainstream science narrative of the Anthropocene illuminate cracks in what, not long ago, was considered the impenetrable structure of Cartesian dualism (Lloro-Bidart, 2015; Lövbrand et al., 2015; Maggs \& Robinson, 2016; Taylor, 2017). The Anthropocene's events have led to realizations around the interdependency of humans and non-humans, raised questions about politics and power, and indicate that a new, more transdisciplinary approach to education and decision making is needed (Castree, 2014; Davis \& Todd, 2017; Latour, 2018; Swyngedouw, 2013). Momentum in many disciplines has built around addressing the issues of the Anthropocene, and it is important, particularly for those in educational research, to take this time to engage with the opportunity that the Anthropocene presents in rewriting our destructive narrative to be more sustainable (Lloro-Bidart, 2015; Lorimer, 2017).

In these turbulent times, science educators and researchers have been called to break with post-positivism, dualisms, and reductionism to settle on new onto-epistemological grounds (Bazzul \& Kayumova, 2016; Haraway, 2016; Lather \& St. Pierre, 2013). Theorists commonly acknowledge that traditional Western ideologies accompanied by their canonical toolkit that brought us the Anthropocene may be inadequate in ameliorating it (Haraway, 2016; LloroBidart, 2015; Lövbrand et al., 2015; Maggs \& Robinson, 2016; Tsing, 2015). One promising proposition (among many) lies in ontologies of process and epistemologies that expand to encompass affect with new combinations of 
knowing/experiencing/researching that honor the more-than-human world we need to navigate (Manning, 2013; Muraca, 2011). Although positing alternative onto-epistemologies propels researchers forward onto alternate and potentially more sustainable ground, possible movements on these new ontoepistemological grounds need expansive, plural exploration, and invention.

This chapter is one such exploration/invention and manifests as methodological in nature. The approaches in this chapter could be considered postqualitative (Lather, 2013; St. Pierre, 2013), post-human (Snaza \& Weaver, 2014), non-representational (Vannini, 2015), and speculative (Shaviro, 2014), but following these burgeoning methodological orientations requires working with no guiding canon. Immanence provides the ontogenetic fabric for this chapter. I specifically work with the philosophies of Erin Manning, a philosopher whose work captured my imagination during an in-depth study of her writing, and who was kind enough to share her unpublished writing around the anarchive with all of the members of the study group exploring her work. I find resonance with Manning's work around Whitehead, who grounds my own commitments to an immanent and processual view of becoming. Additionally, Lather's and St. Pierre's (2013) call to push the boundaries of humanist qualitative research catalyzes this chapter's process of becoming.

Inspired by these theorists, I perform an alternative inquiry technique using elements of magical realism to explore tensions in the classroom. The genre of magical realism combines familiar realist techniques of thick description of everyday life with magical/fantastic elements to invite the reader to experience the mundane in different ways. This chapter invites the reader to consider alternative methodological approaches that may provide new openings, visions, experiences, and imagination amidst the problems of the Anthropocene and provides one example that I hope will inspire plural and divergent approaches to research. In this chapter, I will introduce anarchival writing, provide an example of magical realism-inspired research writing, and explain the elements of magical realism that may contribute to works that reverberate with themore-than-human world of the Anthropocene (Faris, 2004; Manning, 2016; Richardson \& St. Pierre, 2005).

\section{Writing Beyond Findings}

St. Pierre (2018) holds a view of connection between post-qualitative research and writing as a process of inquiry. Often, in traditional research, we are writing up our findings and reporting in a staid representational way that she refers to as the "linearity of the conventional qualitative research report" (St. Pierre, 2018, p. 605). She relates an instance where she did not intentionally write a sentence, but "it wrote itself" (St. Pierre, 2018, p. 605). I highlight this section of her text as it resonates with me; I have been involved in composing in dance, painting, writing, and even teaching where something occurs that I did not intend, but that I am not separate from either. This generative process that is not centered on the conscious intention of the researcher can be seen 
as part of research and may open up inquiry to the more-than-human. This feeling of only being a small part of the writing that "you" produce provides us with an entry point to talk about research that may be anarchival or beyond archival. It may imply that this new body created, in the case of St. Pierre (2018), her writing, is now a more active, living work resonant with ontologies of immanence. Not all writing seems to work this way; as Richardson and St. Pierre (2005) explain, traditional training in writing mires researchers in static representations or writing up findings.

Banks (2008) argues that the very notion of "findings... entail the idea that something preexists to be found" (p. 157), which indicates a specific view of reality, that of fully formed objects out there waiting to be known. This knower/known divide remains haunted with dualisms that have often been cited as fundamental problems of thought leading to our current unsustainable state, the Anthropocene (Haraway, 2016; Maggs \& Robinson, 2016). Although, many researchers purposefully eschew positivist leanings, employing a variety of alternative theoretical frames, they often conform to conventional research format standards by reporting findings (Banks, 2008).

Manning (personal communication, October 30, 2018) would argue that the practice of reporting findings is more like archiving with its appearance of ordered, categorized, and authoritative truths. Reporting findings works well in ontologies of substance, but ontologies of immanence do not fit so squarely with the idea that findings pre-exist the reporting of them. Manning suggests anarchiving as a practice to move toward more active work as described by St. Pierre, but Manning understands that this task is not without obstacles.

\section{A Case for Anarchival Writing}

Manning (personal communication, October 30, 2018) begins her introduction of the anarchive by presenting a conundrum:

The thing is, all accounting of experience travels through simplification-every conscious though, but all in a more minor sense, every tending toward capture of attention, every gesture subtracted from the infinity of potentions. And so, a double-bind presents itself for those of us moved by the force of potential, of processual, of the in-act. How to reconcile the freshness, as Whitehead might say, of process underway, with the weight of experience captured? (pp. 1-2)

The question that Manning (personal communication, October 30, 2018) poses is that if we capture an event in, "the ubiquitous model of description" (p. 2) how can we retain the activating potential that the event embodied in real time (the in-act of experience)? If we cannot retain this potential action, we are left with mere information to be transmitted and consumed in research reports with definite findings. An inability or unwillingness to include potential action leaves us with less likelihood of producing new movement or thought, as Manning (2013) cautions readers that "there are few starting points as lethal [to new thought] as the totalitarianism of Being" (p. 46). 
This brings us to question not only the goal of research being finding preexisting somethings, but also to question representation. "Most contemporary social scientific research ends up... focusing on things that are stable, static, complete" (Vannini, 2015, p. 15), that totality of Being that Manning warns about. This focus results in representation, and "ordinarily, representation is bound to a specific form of repetition: the repetition of the same. Through representation, what has already been given will come to have been given again" (Doel, 2010, p. 117). The danger here is that traditional representational research, concerned with validly portraying what currently exists, may not lead us to any "politico-epistemic renewal" (Vannini, 2015, p. 3) needed to make the Anthropocene "as short/thin as possible" (Haraway, 2016 , p. 160). In other words, the same systems of thought that makes it easier to imagine the end of the world than alternative politics may be, in part, supported by techniques of representation in that new thought is muted through continued reification. Additionally, many argue that attempting to represent an objective reality reinforces human exceptionalism, which is often cited as paving the road to the Anthropocene (Lövbrand et al., 2015; Muraca, 2011; Springgay \& Truman, 2018; St. Pierre, 2018). This is not to say that conventional representational research has no place, but I join others in the call for more experimentation and space for multiple forms of research (Springgay \& Truman, 2018; St. Pierre, 2018; Vannini, 2015 ).

Anarchival writing may be one type of writing that can bridge the conventional to the experimental, and Manning provides some guidance in the creation of such texts. She says that "anarchiving needs documentation-the archive-from which to depart and through which to pass. It is an excess energy of the archive" (Manning, personal communication, October 30, 2018, p. 21). Here the archive acts as a springboard. For example, thick description that comes with traditionally recognized forms of qualitative research may be one way of writing through/toward a more active creation as long as we go beyond just archiving and describing.

One last key to anarchiving needs to be explained, that of beauty. For Manning (personal communication, October 30, 2018) thinking with Whitehead, the strong concept of beauty is not the harmonious symmetry of "external aesthetic judgment" (p. 24). Instead, Whitehead (1933) calls the strong concept of beauty Intensity Proper, filled with difference and conflict, discordant and creative tension that intensifies toward novel becoming. Manning (personal communication, October 30, 2018) explains this beauty, saying "it is operative and felt more than it is seen. The beauty works on us more than we possess it, moving us with its more-than human intensity" (p. 24). Whitehead (1933) describes Intensity Proper as the strength of experience in the process of becoming, the excess that is so often excised when we aim to capture experience objectively through representation.

Manning suggests that when we try to convey this beauty in our experiences conscious intention may get in the way. Whitehead (1933) explains that "consciousness is the weapon which strengthens the artificiality of the occasion of 
experience. It raises the importance of the final Appearance relatively to that of the initial Reality" (p. 270). For Whitehead and Manning, actual objects exist, but they are artefacts of reality, or the process of becoming. Conscious intention and thought latches on to these objects, foregrounding them as actual and true (which they are), but placing all importance on their existence at the cost of excising the process of becoming. So, when St. Pierre (2018) claims that a sentence wrote itself, we might assume that she was part of a process that was not entirely conscious and subject to beauty in the form of Intensity Proper.

Including consciously thought description and moving toward beauty requires that we consider how events, entities, and occasions become. This paper takes Manning's view of immanence through process. For Manning (2013) and Whitehead (1933), definite bodies are ephemeral, phasing into individual existence and dephasing out in a constant process of becoming with/through a field of relation. Normal, conscious "knowing" is often conveyed in qualitative research through thick description. Now, imagine that there are other forces at play or at play differently as experience happensshades of experience, what could have been, what is not, the intense beauty of the experience. These other forces are known "at a different register" (Manning, 2013, p. 24) that is not conscious thought. Manning collectively terms these forces as affect.

It is how to convey this affect, this excess of the static, captured events, entities, and occasions that this chapter is concerned with. This excess that is often excised in representation may be the site of novel creation, breaking open previously unimagined possibilities. Manning (personal communication, October 30,2018 ) argues that techniques must be invented that allow for anarchiving, and hints that artfulness, intuition, changes in direction, and attunement to the minor gesture may aid in the invention of those techniques. Richardson (2003) suggests that writing can be a process of more-than also, but it depends on the forms and styles and involves approaches to writing research differently than traditionally "telling what you know." Manning herself engages in interactive art projects in a resonant way to that suggested by St. Pierre (2018) on writing as inquiry.

In response to this call for experimenting and inventing techniques for anarchiving, I explore the possibility of using magical realism in writing qualitative inquiry. This chapter marks the beginnings of my exploration, so next, I will share some magical elements in the following magical realism-inspired excerpt.

\section{Live SCIENCE}

Mrs. Foster sighed as she taped the last name tag on the red plastic crate. When Principal Trask told her three weeks ago that she would be the first teacher to receive new tables, she had begun planning immediately. The old desks were clunky, stocky numbers sporting rectangular laminated tops over a cavernous metal clad space where students kept their books and binders and 
stuffed any number of odds and ends. Mrs. Foster shuddered thinking of some of the things she had pulled from those metal under-compartments just today.

"This will be better in so many ways," she murmured to herself.

Now the books and binders were stately arrayed, standing on end in the crates, each labeled with a student's name. No snot-filled tissue or exploded glitter pen would hide for months on end in the back of a desk compartment. Mrs. Foster looked out the window toward the teachers' parking lot, where only three cars remained. Although she had spent each day since learning of the impending arrival of the new tables ordering, organizing, clearing, and cleaning, this last day, the day of arrival, had left her at school several hours past the clamor and clang of students leaving for home.

Mr. Trask had selected Mrs. Foster as the new table pioneer for several reasons. Her classroom stayed meticulously arranged, she came an hour before and left an hour after students, and her test scores were among the top in the district.

When he informed her of her vanguard status with regard to the new tables, he said, "I have every confidence that you will work out the kinks without slowing down your class's pace, and I would very much appreciate it if you could present your strategies for classroom set-up and management around the new tables at the staff meeting on the Friday after you get your tables. Lots of pictures would be nice."

Mrs. Foster picked up her phone and started snapping pictures. She had arranged the twenty new desks into tables of four. Each desk had the name of a student printed in neat hand with dry erase marker. Directly on the desk! Upon first learning of this new feature, Mrs. Foster discussed it with some of the other teachers in the teachers' lounge.

She had admitted to the other teachers, "I am not sure if I like it or not."

The other teachers made some suggestions, but most agreed with Ms. Atkinson when she said, "It sounds like a nightmare, they will be distracted trying to write on their desks, they might try to write on other things inappropriately, and what if they use a permanent marker?".

Mrs. Foster made one last sweep of the room to make sure that all of the permanent markers were secured in her desk drawer and then headed out the door, flicking the lights off as she went.

The behavioral chart and some of the other anchor charts took an instant dislike to the new tables. They were a stretch to far out of their comfort zone. Instead of being rectangular or square, something they could easily relate to, they were triangular. The only straight lines apparent on their bodies were the two edges of the triangle making a rounded point, and those were obscured when joined to the other desks making a large round table. Even the outer curve of the tables was not a clean curved line; they were slightly wavy. Wavy, indeed! Who had ever thought of such a thing for children! The behavioral chart felt as if she would have to work extra hard now to add more structure and guidance to the classroom with the chaos of wavy edges added to the mix. 
The tables, for their part, sat patiently, not too bothered by the whispers and tittering of their less solid classroom brethren hanging on the wall. They waited for the children, because of all of the other classroom objects, they and the chairs were most physically connected to the children, and it would be the children that shaped their lives most.

$$
* * *
$$

Tuesday morning burst through the windows in rays of sun, and Mrs. Foster surveyed the new set up with a more energetic eye. She smiled as she moved to the door. The rumble of conversation, barks of laughter, and squeals lessened as she appeared in the doorway. Facing her students down the hall and counting to ten in her head, she waited for her students to shuffle, squeeze, and bump into a fairly straight line.

With a smile she said, "We have a new seating chart, so after you enter, put your things away and find the desk with your name."

She turned her smile on the first student in line and asked, "So Analise, what are we feeling like today?".

Analise glanced to the right, and tapped the heart, indicating that her preferred greeting would be a hug. Mrs. Foster, being fairly short, only bent a little to embrace Analise before stepping aside and officially letting Analise into the classroom.

Mrs. Foster had been doing door greetings since the beginning of the year. She thought back to the day she sat at a long, molded plastic cafeteria table, taking precise notes during the district's professional development around student-centered teaching. In her spiral-bound notebook, she wrote:

Greet Students at Door

- creating a classroom community begins at the door

- greeting conveys to each expectation of engagement

- great way to build relationships (important for student-centered)

During the lunch break, she spoke with some of the other teachers, who suggested various greetings like a fist bump or a high five. Later that night, she surfed the web for more ideas and decided on fist bump, high five, hug, and dance (for students who did not want to touch). In the week leading to the first day of school, she printed out enlarged clip art of two fists bumping, a heart for a hug, the palm of a hand for a high five, and a musical note for dancing. After laminating them, she stuck them to the wall by her door with mounting putty in a neat vertical line. Most students liked to mix it up, one day with a hug another with a fist bump, but there were some students like Lupe, who always chose a hug, and Bella, who always chose a dance.

Some minutes later after a combination of hugs, dances, high fives, and fist bumps, Mrs. Foster stood by her desk at the far end of the room, counting in her head again as she waited for her students to settle down. Normally, by the 
fifth month of school, her stillness and presence were enough to garner their attention, but today the students chatted excitedly past the count of fifteen. She held up her hand, high above her head in a peace sign. Slowly a wave of little peace signs rose in response as those students closest to her noticed her gesture for attention and stilled, thus signaling to those closest to them it was time to pay attention until the whole room was a forest of peace signs at different heights.

"I know the new desks are exciting, but we still have our rules and procedures," Mrs. Foster said as she pointed to the anchor chart of rules and the shiny, laminated behavioral chart adorned with clothes pins in a festive array of colors each with a student's name printed in black Sharpie.

"Remember," she added as she reached for the clothes pins, "everyone starts out on the 'ready to learn' block, but I did notice a few of you who were ready and organized when I first walked into the room. Great job Jasmyn, Aiden, and Marcus," she said as she moved each of their pins to the block labeled "great choice."

"Okay, before we start with math, I think maybe we should share what we think about the new tables. There is a dry erase marker in the small plastic tray under your desk, find it, and hold it up once you have it," Mrs. Foster said as she held up her own dry erase marker and walked slowly around the tables.

"You may write on your desk with this marker ONLY," she said, drawing out the word only.

"What I would like you to do right now is write one word to describe what you think of your new desk."

As she walked around the room, she saw the word "awesome," several times, sometimes spelled without one of the e's. She also saw "weird," spelled "wird," "small," "shiny," "new," and a variety of other descriptors.

A bevy of hands shot up after Mrs. Foster announced, "Okay, time to share."

"Miguel, you wrote awesome, so why is the new desk awesome," she asked as she wrote the word awesome on the board to demonstrate the correct spelling.

"Well, um, I think it is awesome because it fits to make a table."

"Naomi, what is weird about your desk?"

"It is a weird shape, and it smells kind of weird."

Mrs. Foster paused while writing weird on the board, glancing back at Lupe, who had her eyes closed and was stroking the arm of Naomi who sat directly next to her. She finished the $\mathrm{d}$ with a sharp downward movement then glided over to stand behind Lupe and Naomi.

Leaning over, she pointed to Lupe's word, "happy," and asked, "Why happy, Lupe?".

"When I run my hands over the desk, it feels like it is laughing, like it is happy," Lupe responded as she took the hint to stop touching Naomi.

"Well these are some great descriptions, does anyone remember what kind of word describes a noun?” 
After calling on various students giving a variety of answers, most examples of adjectives, Amanda said "adjective," and then the math block began.

Mrs. Forster gave a brief mini lesson as a review; after, the students sat quietly, working on their double-digit multiplication math worksheets. Mrs. Foster circulated around the tables stopping, checking students' work, occasionally exclaiming in praise or correcting some mistake. As she was telling Diego how nice his handwriting looked, she noticed Lupe stroking Naomi's arm again.

Crouching down by Lupe, Mrs. Foster said, "Lupe, what does number three of class rules say?".

Without looking up at the chart, Lupe murmured, "Keep hands, feet, and objects to yourself."

Mrs. Foster glanced at the desks standing off to the side of the room, the only old desk she had kept, and asked, "Lupe, would it help you to sit away from the other students?".

Lupe shook her head, never looking away from her math worksheet.

Mrs. Foster sighed, "Okay, well consider this a reminder then."

She straightened and walked over to the behavioral chart moving Lupe's clothes pin down from "ready to learn" to "reminder."

Mrs. Foster stared at the chart. She recalled speaking with a few of Lupe's other teachers in the teachers' lounge a few weeks ago.

"She just won't stop touching her classmates, and it does not seem to matter who she is sitting by, stroking arms, hair, sometimes just resting her hand on their shoulder. I don't know what to do about it. I was hoping that some of you may have come up with some strategies," Mrs. Foster had said, slightly deflated.

"I really haven't noticed that, but in art we are usually using our hands and Lupe has produced some amazing pieces."

"I haven't either, in robotics club, she is pretty talented-again we are using our hands a bunch there."

"Is she hurting other students? Have they complained?"

"No, but Lupe is sometimes so distracted with touching that she does not finish her work, and I worry that she is distracting other students. I think it might be a nervous habit, maybe if I gave her something touch, like a stress ball or something, it would help, but I also worry that something is wrong. She does it ALL the time."

Mrs. Foster glanced back at Lupe, who was stroking a small stuffed baby tiger with enormous eyes. At least she had stopped touching Naomi, but she still seemed more engaged in touching than doing her math worksheet. Despite having selected table mates for Lupe that usually did not liked to be touched, they did not seem to mind when Lupe touched them. Mrs. Foster had to remind her again to stop touching, this time, Adam, on the other side of her at the table. Lupe's pin on the behavioral chart was now on "stop and think," only one block up from "contact home." 
When Lupe came back from recess, Mrs. Foster pulled her aside and said, "I think maybe we should move you to the desk over there," pointing to the lone, old desk at the side of the room.

"I would hate to have to call your parents again, and we still have one more lesson today-I think this will give you some space to focus."

"Can I write on my desk one more time?" Lupe asked.

Caught off guard by the request, Mrs. Foster stammered, "Um, sure, okay."

Lupe went to her new desk and wrote 'it's okay' then gathered her things including the bubble-eyed tiger and sat at the isolated desk off to the side as Mrs. Foster stood in the center of the classroom and announced amid glad whispers, "We have science today."

She instructed one table at a time to find their crates and get their science notebooks.

When all of the students' notebooks were sitting expectantly on their desks, she smiled and said, "I have a surprise for us today," as she held up a small circular clear plastic dish with something resting on it.

"Mr. Martin found a dead bee yesterday in his garden, and he heard that we were studying pollinators, so he brought it for us to look at."

Pointing to the board, she continued, "Here is a diagram of a flower with labelling boxes, underneath there are words with definitions. If your table does not have the bee, I want you to be working on the flower diagram, draw it in your science notebook, copy down the words and definitions, then try to label as many parts as you can. If the bee is at your table, I want you to draw the bee, on a different page and write down as many observations as you can. Remember, observations are done with the senses, in this case you are not going to touch or taste, but you can smell, listen, and look. Okay Shawn, what should you be doing if your table does not have the bee?".

"Working on the flower diagram in our notebooks."

"Great. Ali, what should you be doing if your table has the bee?"

"Um, draw it and write down observations."

"Yes, draw it and write down observations on a different page. Aiden, what senses are we not going to use during our bee observations?"

"Taste and touch."

"Great job paying attention," she said as she moved all students' pins that were low back to "ready to learn."

"Are there any questions before we get going? Yes, Adam?"

"Should we pass the bee to the next table when we are done?"

"Good question. I will give each table six minutes with the bee, then $I$ will take it to the next table. Okay, let's get started."

In the last ten minutes of class, Mrs. Foster placed the bee on Lupe's desk. Lupe bent low, coming to eye level with the bee then raised up hovering her ear over the bee. Her head jerked up, and she glanced around, making sure that Mrs. Foster was occupied. Seeing her crouching at a table across the room pointing at Lily's notebook, Lupe reached out a finger and pressed it gently on the bee. Lupe closed her eyes and drew in a deep breath, letting it out 
slowly. Adam noticed Lupe touching the bee and stopped his drawing, staring at Lupe and the bee, waiting.

Lupe drew back her hand and stared intently at the bee. Adam raised up a bit in his chair to get a better look at the bee. It seemed to be wiggling, but he could not tell without standing up. Suddenly, the bee rose up, buzzing slightly, staggering a bit in flight, then zipped away. Adam could not control a delighted giggle, and Lupe glanced over at him and beamed.

Mrs. Foster looked up at the clock, and straightening hurriedly saying, "Sorry guys, I guess I lost track of time, go ahead and put up your notebooks, and we will start here next week during our science block."

In the rush to get everyone ready for the end of the day, Mrs. Foster forgot about the bee until after the students had gone. The plastic tray sat empty on her desk. After looking about the desk, she gave up with a shrug, thinking maybe one of the children took it. She remembered that Lupe had the bee last, so she went to Lupe's notebook to make sure that she had gotten a chance to make observations. There in her list of observations Mrs. Foster saw that Lupe had written buzzing and flying. She made a mental note to review inferences with the students at the beginning of the science block next week.

\section{Magical Realism: A Guide}

In magical realist text, authors weave impossible elements into realistic elements without explanation or world-building. The world in magical realism is our "real" world, recognizable through its thick description in the text. The magic in this world is treated just like everyday events. The characters and the classroom above are fictional; the details, events, and actions are all composites of real classrooms that I have observed or participated in during my years of teaching and researching-with the exception of the bee coming back to life. The excerpt demonstrates four of the main characteristics cited by Faris (2004) in her book Ordinary Enchantments, found in magical realism: the irreducible element of magic, defocalization, non-linear sequencing, and a realistic, everyday world.

The irreducible element of magic exists in the text defying universal laws of Western empiricism. Here the element of magic is irreducible because it is presented in text just as it is, presented with detail and certainty, with no extra explanation; it is presented just as factually and descriptively as everyday occurrences. Faris (2004) claims this element can evoke different responses from readers and embody central, political issues in the text.

The jarring appearance of the magical can interrupt the lulling realism, increasing a reader's participation in the text, creating an experience between the text and the reader that is novel. This contrast draws the reader into more attention and an active creation with the text. Magical elements disrupt normal reading habits and ask the reader to co-create/co-think with the text. For example, Lupe's resurrection of the bee may lead readers to reconsider her incessant touching of other students as something other than a nervous 
habit or further reconsider any student's odd behavior. Eliciting more consideration could be particularly valuable in creating anarchival texts that move forward from one author's writing to the reader's creation of novel ideas that are related to the text but not mimetic.

Additionally, the sensory detail that accompanies magical elements allows authors to textually embody forces at play that are not normally tangible in the moment of experience, like the effect of political or cultural realities on the shaping of a place and lives. Rushdie, the author of Midnight's Children, another magical realist text, writes that "realism can no longer express or account for the absurd reality of the world we live in-a world which has the capability of destroying itself at any moment" (as cited in Faris, 2004, p. 88). This suggests that if we include magical elements in realistic texts that we may be able to convey Manning's more than within the singularity of a specific experience. As Mrs. Foster does not know everything about Lupe's touching, this could indicate that, although she seems to be a diligent teacher, it is difficult to know everything about students' concerns and abilities and that students have their own reasons and worlds. The magical can bring in the threads of the rest of the world in both a temporal and geographical sense to the actual occasion of experience as magical realism has no allegiance to normal sequencing of events or static location. This is seen in the text above with the flashback sequences and Mrs. Foster's planning that seem to also be part of the present action, indicating that each action that we perform carries previous and anticipated actions.

This respects the breadth of the anarchive when Manning (2013) explains that "any occasion is at once the absoluteness of it-self in the moment of its concrescence and the will-have-become of its tendencies attunements, appetitions, both past and future" (p. 24). Our current experiences are heavy and pregnant with both the influx of the past and the pull of the future, and magical realism can provide a way to bring this together, often by collapsing time and bringing in specters of the past or with prophetic experiences.

Concerning the anarchive, this irreducible element may be key to writing in a different register so as to know in a different register as suggested by Manning. In other words, the contrast of the magical element allows the reader to reexperience the realist part of the text, inviting them to speculate on what else it might mean, opening the text to their own experiences through the disruption to the real that the magical element can cause. It may also be able to engage the reader in novel ways of creating/thinking by providing a text that offers glimpses of the whole world within the microcosm of magically enhanced mundane experience.

I also employed defocalization, a term coined by Faris (2004), referring to a narrative style that accentuates multivocal perspectives enhanced by the irreducible element of magic. In magical realist text, the perspective shifts fluidly from person to person and even to objects. Realism typically employs focalization that "originates in an individual's consciousness," Faris explains: 
Because realism attempts to create an accurate picture of the world as it is experienced by ordinary human consciousness, readers of realistic fiction are most familiar with focalizations that seem to be grounded in empirical evidence, the quantity of sensory data enhancing the reader's confidence that this representation is accurate and causing the reader to invest in the narrative's picture of the world with authority. (2004, p. 44)

Faris (2004) goes on to say that magical realism takes advantage of the realist habit of deep sensory description but uses the irreducible element of magic to decenter the perspective from the human to the more-than-human. The presence of perceived magic, described sensually, creates a dissonance in the reader. The reader knows that no human could perceive magic carpets, floating priests, and bee resurrections, so they are left with a sense that the narrative perspective comes from an other-than-human consciousness.

These shifts of narrative focus both between the magical and the real and across different characters challenges representation's authority. Faris (2004) explains that the realist description of the magical from an unfamiliar/unknown perspective challenges the norms of realistic representation and undercuts the assumed authority of realism from within. Magical realism questions realism's authority in the function of representation and creates a space where realism is deconstructed while simultaneously employing its representational power.

So, in addition to defocalized narration opening up a way to write the morethan-human, it also provides a space to push representation past its inherent stasis. Manning (2016) says that representations functions at the level of actual bodies, archiving something static that can, at best, only weakly echo affect, the live potential within the in-acted experience. It is this virtual potential that the anarchive must create so as to move new, yet related thought forward from one piece of work to another.

What makes magical realism so compelling in this sense is that it does not discard realist, sensual representation but modifies it to take new directions. The text above mostly describes the mundane and every day. This too is in line with advice from Manning. As mentioned earlier, she contends that the anarchive uses the archive as a springboard; they are not mutually exclusive. Additionally, she sees movement of ideas within constraint to be a powerful tool for creation of novel ways of thinking. She explains that habits, like that of representational authority in qualitative research, structures our thinking and doing, making our work predictable and comfortable, and although this seems to be directly opposite of what she advocates in anarchiving, she sees a path where habit is not discarded but pushed-asking "what else can habit do?" (Manning, 2016, p. 87). She writes that:

Habit... is a mutable force. Habit directs our movements, constraining other tendencies. These other tendencies, constrained as they are, can be said to still be operative... The challenge is to make these minor tendencies operational, 
thereby opening habit to its subtle multiplicity and exposing the fact that habit was never quite as stable as it seemed. (Manning, 2016, p. 87)

This breaking open of habit is what we see Faris (2004) describe in magical realism; by employing traditional (habitual) realist representation but imbuing it with the irreducibly magical, representation is both challenged and transformed to encompass affect, the force of becoming. As writers, a technique that allows space for the more-than, is valuable if we wish our work to activate potential in other works not yet complete-or in short to anarchive.

Employing magical realism elements in qualitative writing as inquiry may allow us to decenter the human and evoke affect in our work. The added benefit remains, that the realist style of representational writing is not discarded, but instead coopted. It is transformed from its habitual mimicry, its static archiving into something more active, more live, possibly more able to drive change. Using realism as a springboard, magical realism presents the opportunity for the reader to be grounded in the concrete empirical observations that are so traditional in the field only to be invited to think more processually through magical realist elements.

I believe that moving with alternative onto-epistemological underpinnings provides a path away from entrenched ways of thought that have culminated in the crises of the Anthropocene. Of course, there exist no panaceas, and the process of reorientation requires adventurous and constant exploration and invention. Proliferation of new techniques and creative works in inquiry may be one way to challenge the status quo that has brought us the Anthropocene by allowing us to imagine, experience, and explore new politics. Although scholarly fiction is not a completely new proposal for qualitative inquiry, magical realism has not been a focus. I contend that anarchival writing of qualitative inquiry with magical elements may be a powerful technique that opens up new directions of thought needed as alternatives in the Anthropocene by challenging the habit of representation and the archive from within.

\section{REFERENCES}

Allen, M. R., Dube, O. P., Solecki, W., Aragon-Duran, F., Cramer, W., Humphreys, S., Kainuma, M., Kala, J., Mahowald, N., Mulugetta, Y., Perez, R., Wairiu, M., \& Zickfeld, K. (2018). Framing and context. In V. Masson-Delmontte, P. Zhai, H. O. Portner, D. Roberts, J. Skea, P. R. Shukla, A. Pirani, W. Moufouma-Okia, C. Péan, R. Pidcock, S. Connors, J. B. R. Matthews, Y. Chen, X. Zhou, M. I. Gomis, E. Lonnoy, T. Maycock, M. Tignor, \& T. Waterfield (Eds.), Global warming of $1.5^{\circ} \mathrm{C}$ : An IPCC special report on the impacts of global warming of $1.5^{\circ} \mathrm{C}$ above preindustrial levels and related global greenhouse gas emission pathways, in the context of strengthening the global response to the threat of climate change, sustainable development, and efforts to eradicate poverty (pp. 49-91). Intergovernmental Panel on Climate Change.

Arva, E. L. (2008). Writing the vanishing real: Hyperreality and magical realism. Journal of Narrative Theory, 38(1), 60-85. 
Banks, S. (2008). Writing as theory: In defense of fiction. In J. G. Knowles \& A. L. Cole (Eds.), Handbook of the arts in qualitative research: Perspectives, methodologies, examples, and issues (pp. 155-165). Sage.

Baskin, J. (2015). Paradigm dressed as an epoch: The ideology of the Anthropocene. Environmental Values, 24, 9-29.

Bazzul, J., \& Kayumova, S. (2016). Toward a social ontology for science education: Introducing Deleuze and Guattari's assemblages. Educational Philosophy and Theory, 48(3), 284-299.

Butzer, K. W., \& Endfield, G. H. (2012). Critical perspectives on historical collapse. Proceedings of the National Academy of Science of the United States of America, 109(10), 3628-3631.

Castree, N. (2014). The Anthropocene and geography I: The back story. Geography Compass, 8(7), 436-449.

Davis, H., \& Todd, Z. (2017). On the importance of a date or decolonizing the Anthropocene. An International Journal for Critical Geographies, 16(4), 761-780.

Doel, M. (2010). Representation and difference. In B. Anderson \& P. Harrison (Eds.), Taking place: Non-representational theories and geography (pp. 117-130). Ashgate

Faris, W. (2004). Ordinary enchantments. Vanderbilt University Press.

Giroux, H. A. (2005). The terror of neoliberalism: Rethinking the significance of cultural politics. College Literature, 32(1), 1-19.

Haraway, D. (2016). Staying with the trouble: Making kin in the Chthulucene. Duke University Press.

Harvey, D. (2005). A brief history of neoliberalism. Oxford University Press.

Johnson, E., \& Morehouse, H. (2014). After the Anthropocene: Politics and geographic inquiry for a new epoch. Progress in Human Geography, 38(3), 439-456.

Lather, P. (2013). Methodology-21: What do we do in the afterward? International Journal of Qualitative Studies in Education, 26(6), 634-645.

Lather, P., \& St. Pierre, E. A. (2013). Post-qualitative research. International Journal of Qualitative Studies in Education, 26(6), 629-633.

Latour, B. (2018). Down to Earth: Politics in the new climatic regime. Polity Press.

Lloro-Bidart, T. (2015). A political ecology of education in/for the Anthropocene. Environment and Society: Advances in Research, 6, 128-148.

Lorimer, J. (2017). The Anthropo-scene: A guide for the perplexed. Social Studies of Science, 41(1), 117-142.

Lövbrand, E., Beck, S., Chilvers, J., Forsyth, T., Hedren, J., Hulme, M., Lidskog, R., \& Vasileiadou, E. (2015). Who speaks for the future Earth? How critical social science can extend the conversation on the Anthropocene. Global Environmental Change, 32, 211-218.

MacGregor, S. (2014). Only resist: Feminist ecological citizenship and post-politics of climate change. Hypatia, 29(3), 618-633.

Maggs, D., \& Robinson, J. (2016). Recalibrating the Anthropocene: Sustainability in an imaginary world. Environmental Philosophy, 13(2), 175-194.

Manning, E. (2013). Always more than one: Individuation's dance. Duke University Press.

Manning, E. (2016). The minor gesture. Duke University Press.

Manning, E. (personal communication, October 30, 2018). Anarchive chapter: What things do when they shape each other.

Miller, T. (2017). Storming the wall: Climate change, migration, and homeland security. City Lights. 
Muraca, B. (2011). The map of moral significance: A new axiological matrix for environmental ethics. Environmental Values, 20, 375-396.

Piketty, T. (2014). Capital in the twenty-first century. The Belknap Press of Harvard University Press.

Plumwood, V. (2002). Environmental culture: The ecological crisis of reason. Routledge.

Richardson, L. (2003). Writing: A method of inquiry. In Y. S. Lincoln \& N. K. Denzin (Eds.), Turning points in qualitative research: Tying knots in a handkerchief (pp. 379-396). AltaMira Press.

Richardson, L., \& St. Pierre, E. A. (2005). Writing: A method of inquiry. In Y. S. Lincoln \& N. K. Denzin (Eds.), The Sage handbook of qualitative research (3rd ed.). Sage.

Rogelj, J., Shindell, D., Jiang, K., Fifita, S., Forster, P., Ginzburg, V., Handa, C., Kheshgi, H., Kobayashi, S., Kriegler, E., Mundaca, L., Séférian, R., \& Vilarino, M. V. (2018). Mitigation pathways compatible with $1.5^{\circ} \mathrm{C}$ in the context of sustainable development. In V. Masson-Delmontte, P. Zhai, H. O. Portner, D. Roberts, J. Skea, P. R. Shukla, A. Pirani, W. Moufouma-Okia, C. Péan, R. Pidcock, S. Connors, J. B. R. Matthews, Y. Chen, X. Zhou, M. I. Gomis, E. Lonnoy, T. Maycock, M. Tignor, \& T. Waterfield (Eds.), Global warming of $1.5^{\circ} \mathrm{C}$ : An IPCC special report on the impacts of global warming of $1.5^{\circ} \mathrm{C}$ above pre-industrial levels and related global greenhouse gas emission pathways, in the context of strengthening the global response to the threat of climate change, sustainable development, and efforts to eradicate poverty (pp. 93-174). Intergovernmental Panel on Climate Change.

Shaviro, S. (2014). The universe of things: On speculative realism. University of Minnesota Press.

Snaza, N., \& Weaver, J. (2014). Posthumanism and educational research. Routledge.

Springgay, S., \& Truman, S. E. (2018). On the need for methods beyond proceduralism: Speculative middles, (in)tentions, and response-ability in research. Qualitative Inquiry, 24(3), 203-214.

St. Pierre, E. A. (2013). The posts continue: Becoming. International Journal of Qualitative Studies in Education, 26(6), 634-645.

St. Pierre, E. A. (2018). Writing post qualitative inquiry. Qualitative Inquiry, 24(9), 603-608.

Swyngedouw, E. (2013). The non-political politics of climate change. ACME: $A n$ International E-Journal for Critical Geographies, 1212(1), 1-8.

Taylor, A. (2017). Beyond stewardship: Common world pedagogies for the Anthropocene. Environmental Education Research, 23(10), 1448-1461.

Tsing, A. L. (2015). The mushroom at the end of the world: On the possibility of life in capitalist ruins. Princeton University Press.

Vannini, P. (2015). Non-representational research methodologies: An introduction. In P. Vannini (Ed.), Non-representational methodologies: Re-envisioning research (pp. 118). Routledge

Whitehead, A. N. (1933). Adventure of ideas. The Free Press. 
Open Access This chapter is licensed under the terms of the Creative Commons Attribution 4.0 International License (http://creativecommons.org/licenses/by/4.0/), which permits use, sharing, adaptation, distribution and reproduction in any medium or format, as long as you give appropriate credit to the original author(s) and the source, provide a link to the Creative Commons license and indicate if changes were made.

The images or other third party material in this chapter are included in the chapter's Creative Commons license, unless indicated otherwise in a credit line to the material. If material is not included in the chapter's Creative Commons license and your intended use is not permitted by statutory regulation or exceeds the permitted use, you will need to obtain permission directly from the copyright holder. 